\title{
Non-Chrematistic Indicators and Growth in the Balearic Islands*
}

\author{
Carles Manera ${ }^{* *}$, José Pérez-Montiel ${ }^{* * *}$, Ferran Navinés $^{* * * *}$
}

\begin{abstract}
We analyze the economic evolution of a Spanish province that has become a leading region in mass tourism: The Balearic Islands. Environmental data are provided, which complement conventional macroeconomic variables. We analyze the relationship between economic activity and the consumption of natural resources in the Balearic Islands during the period 2000-2017.

We find two clear patterns, one before the Global Crisis, and another one after it. We state that the Balearic economic model has become more sustainable since 2008. It implies that public policies, together with own households' and enterprises' initiatives in terms of changing production and consumption patterns have paid off and should be continued and deepened.
\end{abstract}

Keywords: Balearic Islands; Economic Growth; Consumption of Natural Resources; Tourism; Panel Cointegration; Global Tourism; Global Markets

\section{The Economy of the Balearic Islands}

Tourism is considered one of the main engines of economic growth and development (see Li et al. (2018) for a state of the art). However, it is also known that tourism has a highly negative effect on the environment. Despite the numerous economic benefits of tourism development (see Archer, 1995; Fayissa et al., 2011; Kumar \& Kumar, 2012; and Brida et al., 2016, among others), the tourism activity contributes notably to carbon dioxide (CO2) emissions, since it is intensive in the use of fossils fuels (Murray, 2002; Becken \& Simmons, 2002; Becken \& Patterson, 2006; Scott et al., 2010; and Murray, 2013, among others). This use of fossils fuels is direct and indirect (since the tourism industry is intensive in the use of electricity, which is generated from fossil fuels).

The Balearic Islands, in the Mediterranean Sea, is probably the most paradigmatic example of a tourism-based growth model: it receives more than sixteen million tourists a year, while its population is just over a million inhabitants. Services (most

\footnotetext{
* The Authors: Manera, C. § 1, Pérez-Montiel, J. § 2, Navinés, F. § 3

** Full Professor in Economic History, University of Balearic Islands (carles.manera@uib.es).

*** Assistant Professor of Economic History, University of Balearic Islands (jose.perez@uib.es)

**** Economist, Economic and Social Council of the Balearic Islands (fnavines@ gmail.com)
}

Manera, C., Pérez-Montiel, J., \& Navinés, F. (2021). Non-Chrematistic Indicators and Growth in the Balearic Islands. Symphonya. Emerging Issues in Management (symphonya.unicusano.it), (1), 85-99. https://dx.doi.org/10.4468/2021.1.9manera.perez.navines 
of them related to the tourism industry) account for the $80 \%$ of the Balearic output; and the Balearic companies are world leaders in the globalization of investments in the tourism industry (Brondoni \& Rizzi, 2017; Rizzi \& Graziano, 2017; Brondoni, 2016; Salvioni, 2016). This could be a tight synthesis of the Balearic economic growth model since the "tourist boom" of the 1970s (Balaguer \& Cantavella-Jordá, 2002; Manera Erbina, 2014). Despite the benefits that the tourism industry has brought to the Balearic Islands, negative tourism-driven impacts on the environment are obvious: emissions of considerable amounts of $\mathrm{CO} 2$, excessive consumption of territory, water, and energy resources, together with the creation of urban solid waste. Moreover, the tourism-based growth model have also led to demographic implosion (Murray, 2002; Murray 2013).

The analysis of the relationship between economic growth and the environment is generally based on the dependence that the former has on consumption of natural resources (Schlupmann \& Martinez-Alier, 1987; Pearce, 1989; Poon, 1993; Pearce, 1998; Sindinga, 1999; Turner, 2012). In the case of the Balearic Islands, research programmes have been mainly cultivated in the academic sphere (Alegre \& Pou, 2002; Garau Taberner, 2010; Murray, 2013), with relatively few impact on active policies. For this reason, we believe that taking into account the evolution of biophysical variables and its connection with the evolution of output is needed to facilitate decision-making pathways (O’Reilly, 1986; Mullins, 1991; Kallis et al., 2012; Pueyo, 2014).

Based on the conclusion that economic growth causes disorder in all areas and, obviously, in the environment, (Georgescu-Roegen et al., 1996; Gössling et al., 2002; Sun et al., 2019) defend extending the range and scope of the analysis of economic processes, including methods and theories from natural sciences. The change is substantial; but it contributes to technically and conceptually enrich the economic analysis (Bridge et al., 2013; Luo \& Bao, 2019; Gössling, 2017). This change moves from a mechanistic phase to a more holistic one, in which the economist is required to dialogue with other disciplines to better understand what happens in his own field (Britton, 1991; Williams \& Shaw, 1998; Bettini \& Karaliotas, 2013).

With this in mind, the present paper analyzes the economy of the Balearic Islands during the period 2000-2017. Our main objective is to provide some economic, social and environmental indicators that help to identify and understand some generally overlooked dynamics of the Balearic economy. We aim at carrying out a first step into the construction and consolidation of a synthetic indicator of sustainability that combines chrematistic and non-chrematistic indicators.

\section{Economic, Social and Environmental Indicators}

Ten indicators have been processed for the period 2000-2015. The series is brief, but it embraces a period of economic expansion followed by the outbreak of the Global economic crisis in 2008:

1. Water consumption (in cubic hectometers),

2. Energy consumption (in equivalent tons of oil),

3. Production of urban solid waste (USW) (in tons),

4. $\mathrm{CO} 2$ emissions (in kilotons),

5. Gini Index, 
6. GDP deflated at 2010 values,

7. GDP per capita deflated to values of 2010 ,

8. Wages,

9. Unit labour cost,

10. Demographic evolution.

The data come from the official Statistics Office of the Balearic Islands (Gini index and wages); the Regional Ministry of Environment, Agriculture and Fisheries (water consumption); the Regional Ministry of Territory, Energy and Mobility (energy consumption and $\mathrm{CO} 2$ emissions); the Island Council (production of USW); and the National Institute of Spanish Statistics (Unit Labour Costs, GDP and GDP per capita)

The indicators and their reciprocal relation are characterised by the following:

1. They do not present unachievable methodological difficulties for data collection and subsequent calculation, so that they can be reasonably assumed as panel discussion by policy makers;

2. Chrematistic variables (GDP, GDP per capita) are intermingled with environmental ones (production of USW, $\mathrm{CO} 2$ emissions, energy use, and water consumption);

3. They do not put aside the social aspect of the process of growth, since they incorporate data on inequality (Gini index) and consumption capacities (through wage indicators). We consider wages, on the one hand, and unit labour costs, on the other, since the former is seen as an important determinant of domestic demand (households' income), while the latter is generally considered as a factor of international price-competitiveness (firms' cost);

4. They help to identify some environmental effects of economic growth;

5. They provide a different reading of the growth process, since they specify and systematize dispersed variables that do not usually appear in the regular diagnoses of public administrations.

One is aware that other variables can be incorporated into this exercise; what is required, though, is that they fulfil at least the five characteristics specified above.

If we put our attention exclusively in the four environmental indicators (water consumption, energy consumption, production of USW, and CO2 emissions) and in the GDP per capita, an evidence is immediately detected: two clear stages are detected in the analysed period (2000-2015). A first one that ranges the subperiod 2000-2007 and a second one that starts from the Global economic crisis on. This distinction, although simple and expected, is important because it entails not only different behaviours of some indicators, but also different readings of the impacts of growth on the consumption of natural resources. One conclusion arises: economic growth causes disorder - therefore, entropic situations from the environmental point of view - ; but such an affirmation, which may seem obvious, hides different characteristics and dynamics depending on the analysed specific stage.

The deflated GDP per capita is 17, 45\% lower in 2015 than in 2000. It presents negative annual growth rates practically in every year (except for the years 2004, 2013 and 2014). On the other hand, water consumption, energy use, CO2 emissions, and USW production grew at positive rates in practically every year before the Global economic crisis; and present negative growth rates in practically every year after the Global economic crisis. Therefore, we see a clearly different pattern of consumption 
of natural resources before and after the Global economic crisis that apparently cannot been explained exclusively by the evolution of current output.

\section{Consumption of Natural Resources and GDP per capita}

Next, we describe apparent relationships between the four environmental indicators presented in the previous section and the deflated GDP per capita. Figures 1-4 show the bivariate simple linear regressions. The results suggest the following considerations:

1. During the period 2000-2007, the bivariate relationships are negative in all cases. All the regressions show negative slope coefficients and statistically significant effects.

2. However, after the Global economic crisis, the Balearic Islands experience a same sign-relationship between GDP per capita and natural resources consumption. From 2008 on, the regression slopes turned positive: the upward or downward variations in the deflated GDP per capita imply same signmovements in the use of natural resources, except for water consumption (however, in this case the slope coefficient is not statistically significative). This suggests that, contrary to what happened during the subperiod 2000-2007, between 2008 and 2015 the negative growth rates of GDP per capita are accompanied by negative growth rates of consumption of natural resources.

Figure 1: Linear Regression between Water Consumption (in cubic hectometer) and GDP per capita

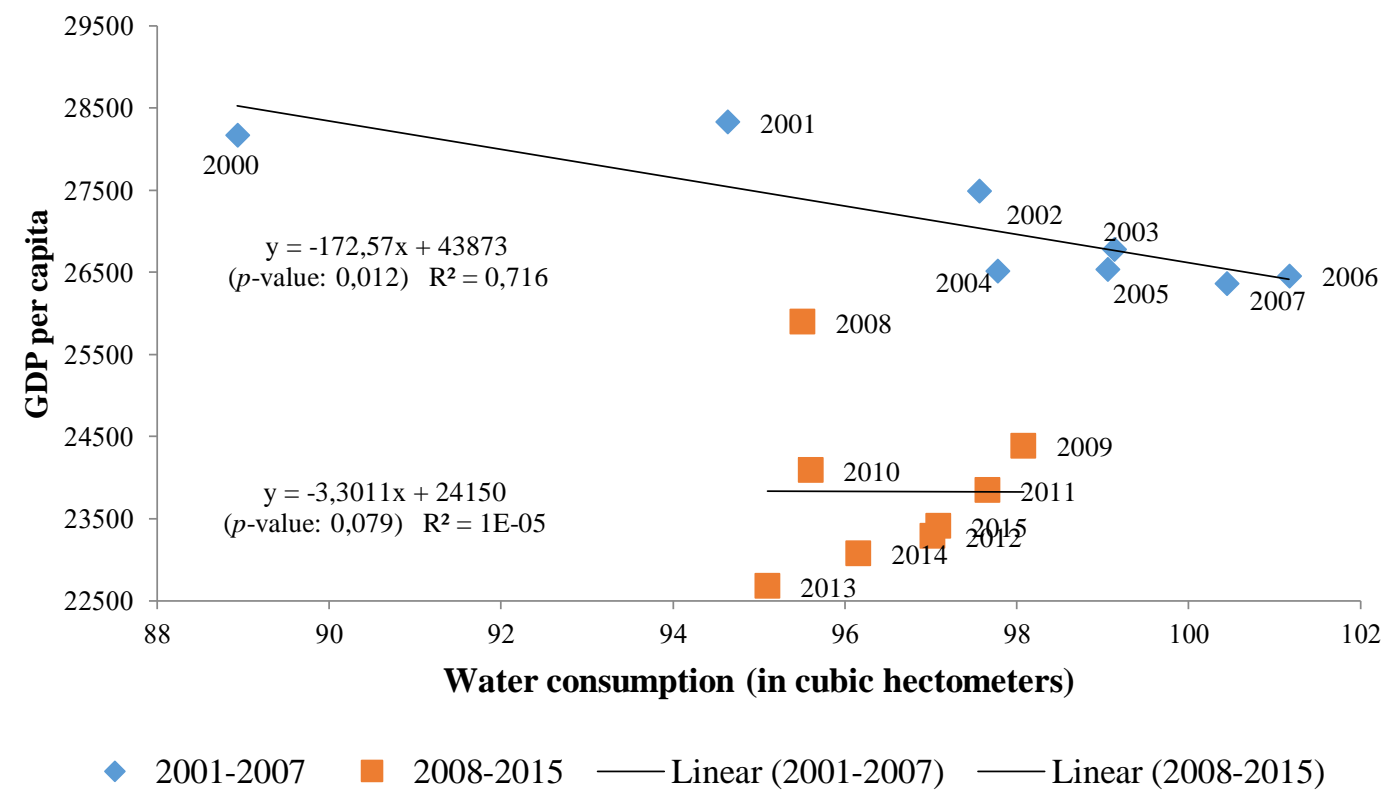


Figure 2: Linear Regression between Energy Consumption (in equivalent tons of oil) and GDP per capita

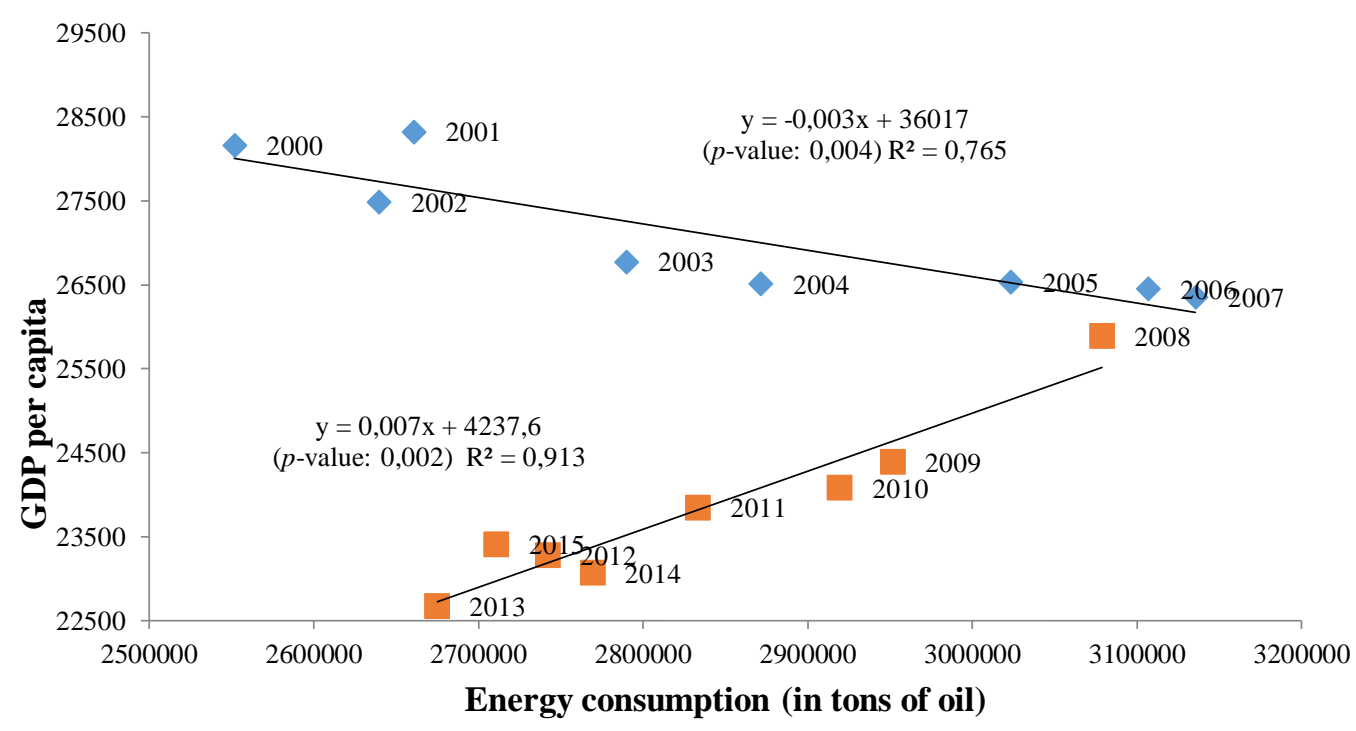

2001-2007 2008-2015 - Linear (2001-2007) - Linear (2008-2015)

Figure 3: Linear Regression between USW (in tons) and GDP per capita

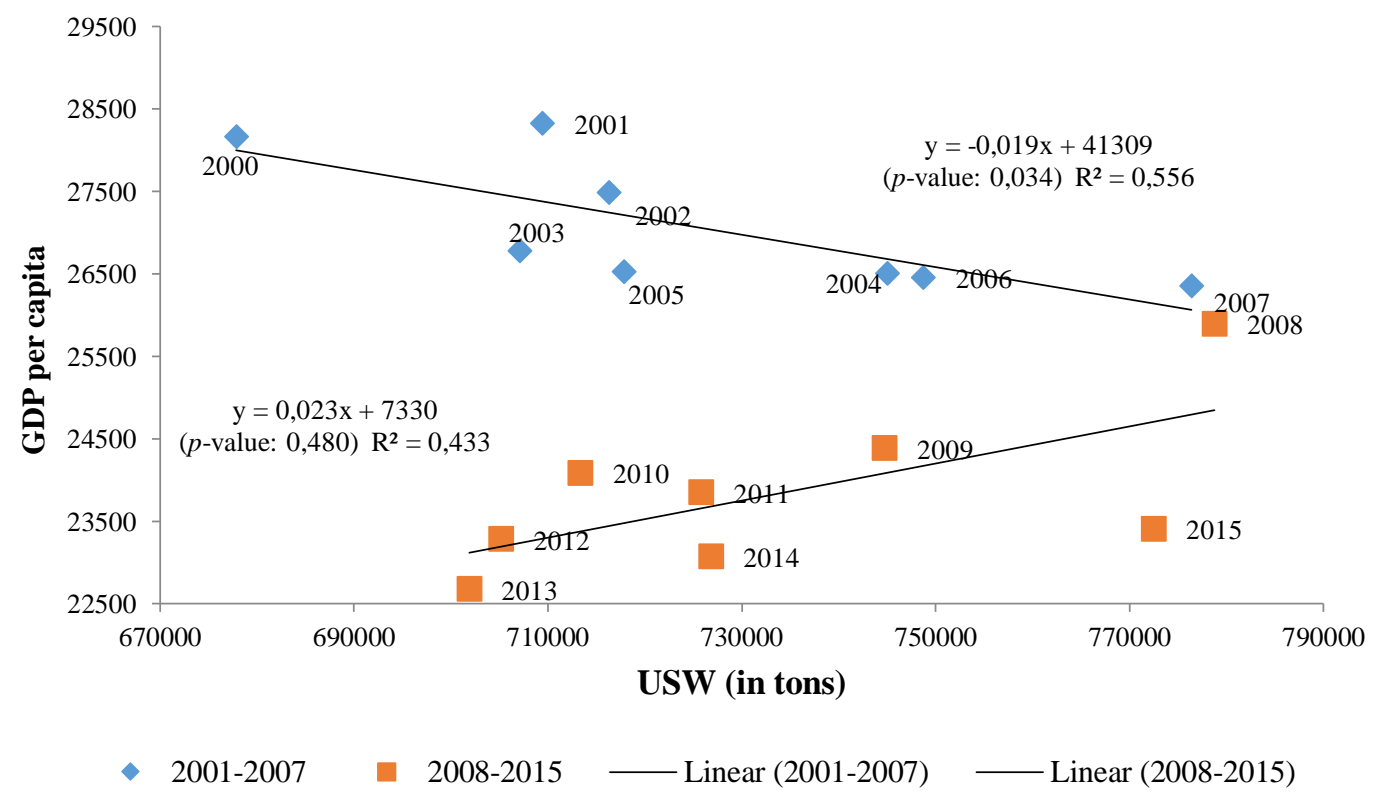


Figure 4: Linear Regression between CO2 Emissions (in kilotons) and GDP per capita

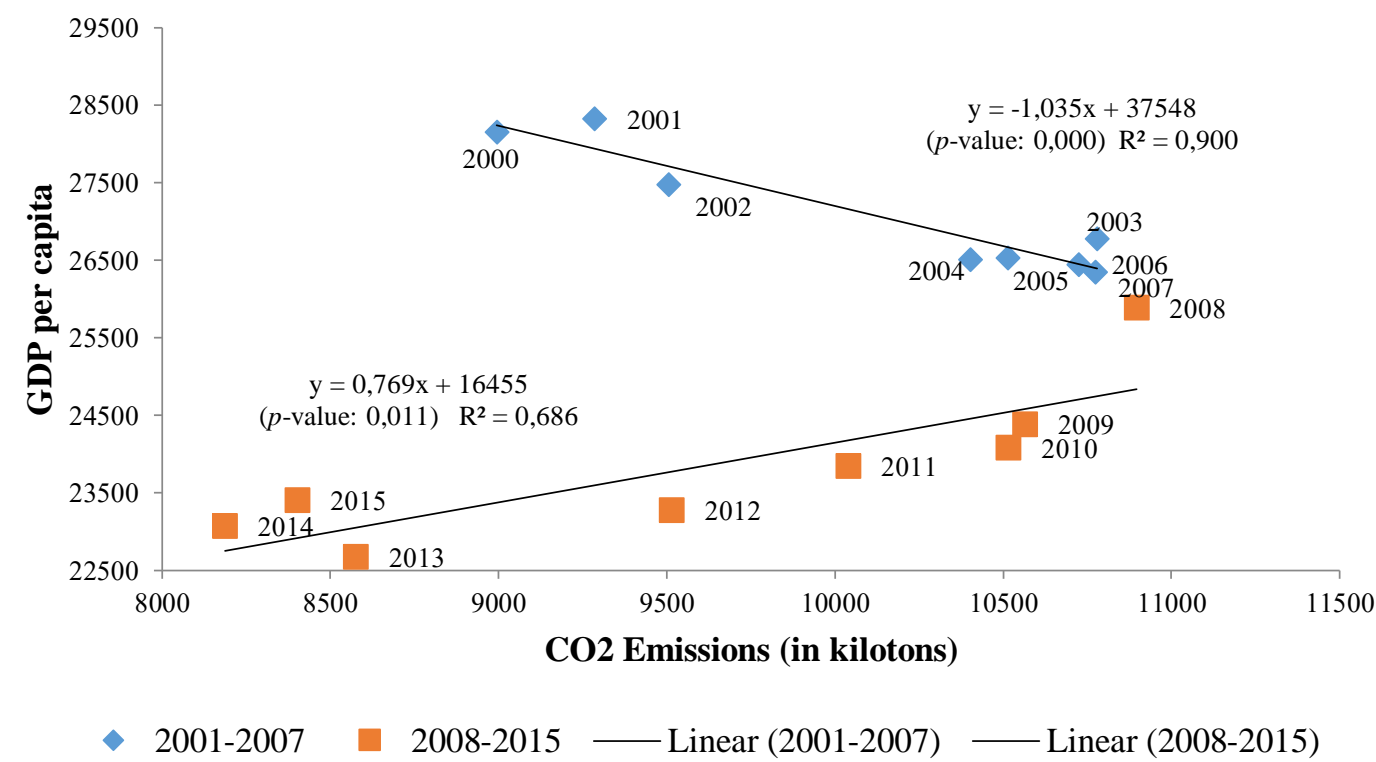

Other comments are pertinent: if we leave aside the demographic evolution and just consider the evolution of real GDP, we see that before the Global economic crisis economic growth was lower than the evolution of energy consumption. The period between 2001 and 2006 was a phase characterised by highs rates of growth of real GDP, which needed however, greater expansions of energy consumption. The economy of the Balearic Islands also needed rates of growth of $\mathrm{CO} 2$ emissions and of production of USW higher than those of real GDP between the period of 2000 and 2005.

From 2006, the evolution of the USW indicator is below the evolution of real GDP. This does not happen with CO2 emissions; which evolve in step with real GDP. In short, between 2000 and 2007, the evolution of the use of natural resources exceeds that of real GDP, which suggests that the economic growth model of the Balearic Islands during this period required a high consumption of energy, water and $\mathrm{CO} 2$ emissions. This is confirmed by the fall of the energy intensity (energy required to generate a unit of output) of the Balearic economy since 2006, after an expansive period (Figure 5). These results suggest the following aspects: on the one hand, an improvement in productive efficiency; on the other, a change in consumption patterns. Another key element can be a change in the economic structure of the Balearic Islands: the loss of the weight that the construction sector (intensive in the use of natural resources) had on output. 


\section{Figure 5: Energy Intensity of the Balearic Economy}

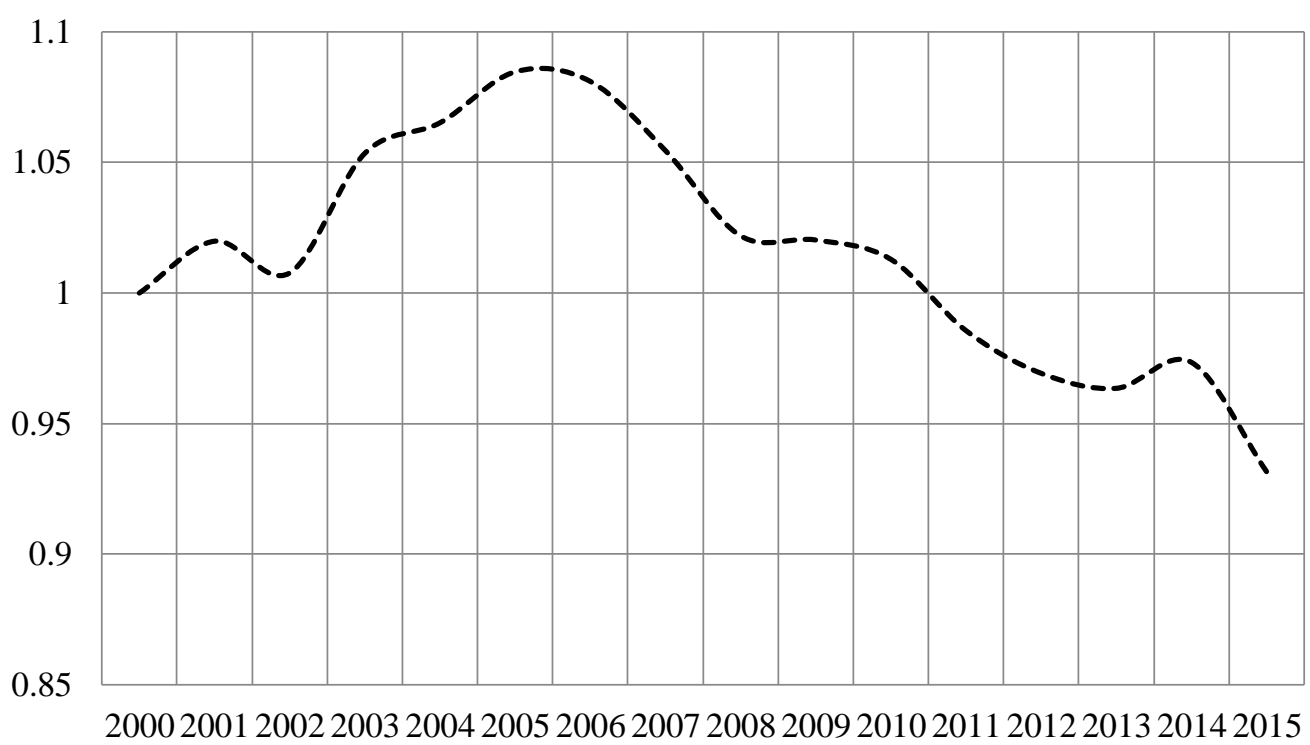

Source: Own elaboration, with regional GDP data and energy use reduced to equivalent tons of oil. The data comes from the Official Statistical Office of the Balearic Islands (IBESTAT) and the National Statistics Institute (INE).

\section{CO2 Emissions and Economic Activity}

Until now our study has been more descriptive than analytic. Since the time dimension of our data is not sufficiently large, we have been unable to carry out a time series analysis to study the dynamic relationship between economic activity and consumption of natural resources. However, we have been able to disaggregate by sectors the data of $\mathrm{CO} 2$ emissions and the data of real GDP. This gives us a crosssectional dimension that, combined with the time dimension, allows us to implement a panel data cointegration analysis to study the dynamic relationship between $\mathrm{CO} 2$ emissions and economic activity in the Balearic Islands.

Negative tourism-driven environmental impacts are inevitable, since most tourismrelated activities involve energy consumption from fossil fuels, thus leading to the emission of a significant amount of CO2 (Paramati et al., 2017: 715). There are many works stating the effects of tourism development on $\mathrm{CO} 2$ emissions (Gössling et al., 2005; Scott et al., 2010; Tang et al., 2014; among others). However, there is no unanimity about the effects of tourism activity on $\mathrm{CO} 2$ emissions. In the case of developing regions that base their development strategies in the tourism industry, considering the numerous studies that analyse the relationship between economic development and $\mathrm{CO} 2$ emissions is also interesting. Many of these papers have been aimed at testing the environmental Kuznets curve (EKC) hypothesis.

The EKC hypothesis is analogous to the hypothesis that Kuznets (1955) applied to study the relationship between income distribution and economic growth. According to Dinda (2004), the EKC hypothesis stablishes that economic growth leads to significant increases of emissions in the early stages of economic development, but then emissions subsequently decline and environmental quality improves. In the field 
of tourism economics, some works such as Weaver (2011) and Scott (2011) suggest empirical evidence in favour of the EKC hypothesis and sustain that public sustainability measures contribute to mitigate $\mathrm{CO} 2$ emissions. Therefore, the relationship between economic activity and $\mathrm{CO} 2$ emissions might not be uniform across regions and time. This is, in fact, what we analyze in the present section.

In what follows, we analyse the dynamic relationship between economic activity and $\mathrm{CO} 2$ emissions in the Balearic Islands. We have a series that covers the period 2000-2017. With the available data, we have been able to disaggregate data of GDP in chained 2010 euros and $\mathrm{CO} 2$ emissions in Kilotons into four sectors: (i) Agriculture, forestry and fishing; (ii) Extractive industries, manufacturing industry, supply of electricity, gas, steam and air conditioning, water supply, sanitation activities, waste management and decontamination; (iii) Construction; and (iv) Wholesale and Retail, repair of motor vehicles and motorcycles, transport and storage, Accommodation. The data on GDP and CO2 emissions provide from the Official Statistical Office of the Balearic Islands (IBESTAT).

We have verified the presence of panel cross-sectional dependence (the four sectors are highly interconnected and, therefore, shocks in one sector affect the rest of the sectors) and panel heterogeneity (different relationships between GDP and CO2 emissions across the different sectors) through the cross-sectional independence test of Pesaran et al. (2008) and the slope homogeneity test of Pesaran \& Yamagata (2008), respectively. Therefore, we analyze the stationarity properties of the variables GDP and CO2 emissions through the panel unit root test of Pesaran (2007), which is robust to both cross-sectional dependence and cross-sectional heterogeneity. The Cross-sectionally Augmented Dickey-Fuller test of Pesaran (2007) indicates that the variables are non-stationary in level and stationary in first differences, i.e., the variables are $\mathrm{I}(1)$ processes.

Having checked that the variables are integrated of order one, we can proceed to the panel cointegration test of Pedroni $(1999 ; 2004)$, based on the Engle \& Granger (1987) approach, which is robust to endogenous regressors and to both crosssectional dependence and heterogeneity. This test constructs seven statistics, four of which are based on within-dimension tests, simultaneously allowing for common time factors and heterogeneity across sectors. The rest of the tests are based on the between-dimension approach, derived by the averages of individual autoregressive coefficients of the unit root test on the residuals of every sector i.

We analyze the following long-run relationship:

$$
\mathrm{CO} 2_{\text {it }}=\mathrm{c}_{\mathrm{i}}+\partial_{\mathrm{i}} \mathrm{t}+\beta_{\mathrm{i}} \mathrm{GDP}_{\mathrm{it}}+\varepsilon_{\mathrm{it}}
$$

where $\mathrm{CO}_{2}$ it represents $\mathrm{CO} 2$ emissions of sector $\mathrm{i}$ in period $\mathrm{t}$, and $\mathrm{GDP}_{\mathrm{it}}$ is the gross domestic product of sector $\mathrm{i}$ in period $\mathrm{t}$, for $\mathrm{i}=1,2, \ldots \mathrm{N}$ and $\mathrm{t}=1,2, \ldots \mathrm{T}$. The parameter $\partial_{\mathrm{i}} \mathrm{t}$ is the specific deterministic temporal trend of sector $\mathrm{i}$, while $\mathrm{c}_{\mathrm{i}}$ allows for common effects that are shared across sectors in any given period t. The slope coefficients $\beta_{\mathrm{i}}$ can be heterogeneous across sectors.

The panel cointegration test indicates the following results. Only two of the seven statistics rejects the null hypothesis of cointegration for the whole period of study (2000-2017), which suggests no enough evidence of cointegration between the variables for the whole period of study. 
Table 1: Pedroni Heterogeneous Panel Cointegration Test

\begin{tabular}{ccccccc}
\hline & Whole Period $(2000-2017)$ & Subperiod $2000-2008$ & \multicolumn{2}{c}{ Subperiod 2009-2017 } \\
& Statistic & $P$-value & Statistic & $P$-value & Statistic & $P$-value \\
Panel $v$-Statistic & 0.15 & 0.44 & -0.33 & 0.63 & -1.24 & 0.89 \\
Panel $\rho$-Statistic & 0.00 & 0.50 & 1.16 & 0.88 & 1.16 & 0.88 \\
Panel $t$-Statistic & -1.18 & 0.12 & -0.96 & 0.17 & $-4.30 * * *$ & 0.00 \\
Panel ADF- & & & & & 0.00 \\
Statistic & -1.23 & 0.11 & -1.00 & 0.16 & $-2.49 * * *$ & 0.00 \\
& Statistic & $P$-value & Statistic & $P$-value & Statistic & $P$-value \\
Group $\rho$-Statistic & 0.74 & 0.77 & 1.38 & 0.92 & 1.36 & 0.91 \\
Group $t$-Statistic & $-1.78 * *$ & 0.04 & $-3.67 * * *$ & 0.00 & $-5.17 * * *$ & 0.00 \\
Group ADF- & & & & & & 0.00 \\
Statistic & $-2.86 * * *$ & 0.00 & $-2.06 * *$ & 0.02 & $-2.88 * * *$ & \\
\hline
\end{tabular}

Note: This table presents the results of the panel cointegration test of Pedroni (2004). Deterministic trend and intercept are assumed. The automatic lag length selection is based on SIC (Newey-West automatic bandwidth selection and Bartlett kernel). The asterisks *** and ** indicate rejection of the null hypothesis of no cointegration at the $1 \%$ and $5 \%$ significance level, respectively.

In the absence of a long-run equilibrium relationship between GDP and $\mathrm{CO} 2$ emissions, we apply the panel short-run causality test of Dumitrescu and Hurlin (2012), which is robust to cross-sectional heterogeneity and cross-sectional dependence. Having verified that $\mathrm{CO} 2$ and GDP are integrated of order one, we consider the following linear model for each sector $i=1, \ldots, N$ in period $t=1, \ldots, T$, based on Dumitrescu and Hurlin (2012):

$$
\begin{aligned}
& \Delta \mathrm{CO}_{\mathrm{it}}=\alpha_{1 \mathrm{i}}+\sum_{\mathrm{k}=1}^{\mathrm{K}} \gamma_{\mathrm{i}} \Delta \mathrm{CO} 2_{\mathrm{i}, \mathrm{t}-\mathrm{k}}+\sum_{\mathrm{k}=1}^{\mathrm{K}} \beta_{\mathrm{i}} \Delta \mathrm{GDP}_{\mathrm{i}, \mathrm{t}-\mathrm{k}}+\varepsilon_{1 \mathrm{i}, \mathrm{t}}, \\
& \Delta \mathrm{GDP}_{\mathrm{it}}=\alpha_{2 \mathrm{i}}+\sum_{\mathrm{k}=1}^{\mathrm{K}} \delta_{\mathrm{i}} \Delta \mathrm{GDP}_{\mathrm{i}, \mathrm{t}-\mathrm{k}}+\sum_{\mathrm{k}=1}^{\mathrm{K}} \theta_{\mathrm{i}} \Delta \mathrm{CO} 2_{\mathrm{i}, \mathrm{t}-\mathrm{k}}+\varepsilon_{2 \mathrm{i}, \mathrm{t}},
\end{aligned}
$$

where $\Delta$ denotes first difference, $\mathrm{K}$ is the number of lags, which is considered qual for every sector. $\gamma_{\mathrm{i}}$ and $\delta_{\mathrm{i}}$ are the autoregressive parameters, while $\beta_{\mathrm{i}}$ and $\theta_{\mathrm{i}}$ denote the coefficients slopes. Individual effects, $\alpha_{i}$, can differ between sectors, but are considered constant over time.

The null hypothesis that GDP does not granger cause CO2 can be represented as follows:

$$
\mathrm{H}_{0}: \beta_{\mathrm{i} 1}, \ldots \beta_{\mathrm{ik}}=0 \quad \text { for } \mathrm{i}=1,2, \ldots \mathrm{N} \text {. }
$$


The alternative hypothesis holds that there are $\mathrm{N}_{1}<\mathrm{N}$ individual processes with no causality running from GDP to $\mathrm{CO} 2$, which is summarized in:

$$
\begin{gathered}
\mathrm{H}_{1}: \quad \beta_{\mathrm{i} 1}=\ldots=\beta_{\mathrm{ik}}=0 \quad \text { for } \mathrm{i}=1,2, \ldots \mathrm{N}_{1} \\
\beta_{\mathrm{i} 1} \neq 0 \text { or } \ldots \beta_{\mathrm{ik}} \neq 0 \quad \text { for } \mathrm{i}=\mathrm{N}_{1}+1, \mathrm{~N}_{1}+2, \ldots \mathrm{N},
\end{gathered}
$$

where $\mathrm{N}_{1}$ is unknown but satisfies the condition $0 \leq \mathrm{N}_{1} / \mathrm{N}<1$.

As can be seen in Table 2, we do not find evidence of heterogeneous panel causality between GDP and CO2 emissions.

Table 2: Pairwise Dumitrescu-Hurlin (2012) Panel Causality Test

\begin{tabular}{cccc}
\hline & \multicolumn{3}{c}{ Whole Period (2000-2017) } \\
\hline Null Hypothesis: & W-Stat. & Zbar-Stat. & $P$-value. \\
\hline & & & 0.83 \\
GDP $\rightarrow$ CO2 emissions & 2.84 & 0.21 & 0.97 \\
C02 emissions $\rightarrow$ GDP & 2.55 & 0.03 & \\
\hline
\end{tabular}

Note: This table presents the results of the short-run heterogeneous panel causality test proposed by Dumitrescu and Hurlin (2012). In order to remove autocorrelation in the residuals, it was necessary to use two lags. However, the results do not change when we use one and three lags (three is the maximum number of lags allowed by the test, given our $\mathrm{N}$ and $\mathrm{T}$ ). The symbol $\rightarrow$ indicates direction of causality. The null hypothesis states non-homogeneous causality.

On the other hand, if we divide the data into two subsamples, the results change. As can be seen in Table 1, there is no enough evidence of cointegration between GDP and CO2 emissions for the period 2000-2008 (only two of the seven statistics reject the null hypothesis of no cointegration); while evidence of cointegration is found for the period 2009-2017 (four statistics reject the null hypothesis of no cointegration). We cannot implement the panel causality test by Dumitrescu and Hurlin (2012) in the subperiods 2000-2008 and 2009-2017, respectively, due to the short span of observations. However, the cointegration analysis suggests that there is a long-run nexus between CO2 emissions and GDP during the subperiod 2009-2017; while during the subperiod 2000-2008 CO2 and GDP evolve independently.

The results clearly reveal two different patterns in the dynamic relationship between economic activity and $\mathrm{CO} 2$ emissions in the Balearic Islands. It is obvious that production generates $\mathrm{CO} 2$ emissions; however, while during the period 20002008 CO2 emissions evolve disproportionally with respect to economic activity, $\mathrm{CO} 2$ emissions and GDP follow a long-run equilibrium relationship during the subperiod 2009-2017. It indicates that after the global economic crisis the Balearic Islands have been capable to develop a certain resilience capacity, being able to reach a more harmonious relationship between economic activity and $\mathrm{CO} 2$ emissions. 


\section{Final Considerations and Future Lines of Research}

The dynamic relationship between economic activity and the consumption of natural resources has allowed us to identify two clear different patterns of sustainable development that probably a more conventional macroeconomic analysis would have not detected.

Economic activity inevitably implies the consumption of natural resources and has effects on the environment. However, during the period 2000-2008 the emissions of $\mathrm{CO} 2$ evolved disproportionally with respect to economic activity. The disproportion was such that $\mathrm{CO} 2$ emissions and GDP did not follow a cointegrating relationship during this period. On the other hand, we observe a more harmonious relationship between CO2 emissions and GDP for the period 2009-2017, since we find a long-run equilibrium nexus between them. It does not mean that the economic model of the Balearic Islands does not face any more challenges in terms of sustainability. However, it suggests that the efforts coming from public policies and own initiatives of households and firms, in terms of changing production and consumption patterns, among others, have not been in vain and, therefore, should be deepened.

Tertiary economies are experiencing fast changes in the process of economic globalisation (Farrell \& Twining-Ward, 2004; Podhorodecka, 2018). At this point, there exist some challenges that directly affect the Balearic economy. The dynamic competitiveness of productive systems consists not only in the ability to adapt to changes, but also in the capability to do it as quick as possible (Morley, 1992; Papatheodorou \& Song, 2005; Maroto-Sánchez \& Cuadrado-Roura, 2009; Rodrik, 2016). Indeed, the speed with which local actors process and execute information, which can be enhanced through cooperation between the different productive units, is crucial.

The agility with which this information is systematised is related to three essential factors. First, the productive resources of the companies, according to their critical mass or size (tangible plus intangible). Second, the implementation of regional and local innovation systems could favour new possibilities that would bring more efficient productive combinations to respond to the demanded changes. Finally, the active role that the public sector would have to assume in order to develop synergies with the private capital, which until very recently had been merely prone to investments (Segreto et al., 2009). These are indeed difficult challenges, but they are being considered by all the regional mature economies.

Tourism as a system is consolidated itself as an integral system for the economy in general (Louis \& John, 1991; Manera \& Navines, 2018). In this sense, working on alternative indicators, which consider the negative impacts that this integral system has on the environment, will be a determining factor in improving the adoption of public policies.

The current difficulties that capitalism faces evidence the increasing importance of establishing alternative and complementary indicators that complement the chrematistic ones. This has been a central objective of our research. We believe that the presented indicators offer reasonable explanations on the evolution of a tourismled economy from the perspective of sustainability. We have argued about environmental aspects, but we have also put on the table social questions for future research. Both the environmental and the social question are basic to obtain a deeper reading of an economy's trajectory. 
The available data for this research does not allow us to distinguish the sectorialization of the economy in terms of consumption of natural resources, except for the case of $\mathrm{CO} 2$ emissions. In this sense, it will be important to connect future research with biologists, chemists and environmentalists to better interpret the available data and facilitate the creation of synthetic explanatory indicators.

In fact, our research is in a primary phase that must be deepened and consolidated by the creation of a synthetic indicator of sustainability. This indicator would be analogous to the Human Development Index of the United Nations, and would incorporate social, environmental and chrematistic variables. The results of the present paper, which indicate a better performance of the Balearic economic model in terms of sustainability during the period 2009-2017, might hide some economic and social problems such as the increment of unemployment and the decrease of the purchasing power of households. This is one of the problems with which the theorists of degrowth handle with more difficulties. Therefore, a synthetic indicator of sustainability that also accounts for the social question becomes crucial for future research.

\section{Bibliography}

Alegre, J., \& Pou, L. (2002). The Determinants of the Probability of Tourism Consumption: An Analysis with a Family Expenditure Survey Llorenç Pou (No. 39).

Archer, B. (1995). Importance of Tourism for the Economy of Bermuda. Annals of Tourism Research, 22(4), 918-930.

http://dx.doi.org/10.1016/0160-7383(95)00018-1

Balaguer, J., \& Cantavella-Jordá, M. (2002). Tourism as a Long-Run Economic Growth Factor: the Spanish Case. Applied Economics, 34(7), 877-884.

http://dx.doi.org/10.1080/00036840110058923

Becken, S., \& Patterson, M. (2006). Measuring National Carbon Dioxide Emissions from Tourism as a Key Step Towards Achieving Sustainable Tourism. Journal of Sustainable Tourism, 14(4), 323-338. http://dx.doi.org/10.2167/jost547.0

Becken, S., \& Simmons, D. G. (2002). Understanding Energy Consumption Patterns of Tourist Attractions and Activities in New Zealand. Tourism Management, 23(4), 343-354.

http://dx.doi.org/10.1016/S0261-5177(01)00091-7

Bettini, G., \& Karaliotas, L. (2013). Exploring the Limits of Peak Oil: Naturalising the Political, DePoliticising Energy. The Geographical Journal, 179(4), 331-341.

http://dx.doi.org/10.1111/geoj.12024

Brida, J. G., Cortes-Jimenez, I., \& Pulina, M. (2016). Has the Tourism-Led Growth Hypothesis Been Validated? A Literature Review. Current Issues in Tourism, 19(5), 394-430.

http://dx.doi.org/10.1080/13683500.2013.868414

Bridge, G., Bouzarovski, S., Bradshaw, M., \& Eyre, N. (2013). Geographies of Energy Transition: Space, Place and the Low-Carbon Economy. Energy Policy, 53, 331-340.

http://dx.doi.org/10.1016/J.ENPOL.2012.10.066

Britton, S. (1991). Tourism, Capital, and Place: Towards a Critical Geography of Tourism. Environment and Planning D: Society and Space, 9(4), 451-478.

http://dx.doi.org/10.1068/d090451

Brondoni, S. M., \& Rizzi, P. (2017). Ouverture de 'Special Issue on Global Tourism Management'. Symphonya. Emerging Issues in Management (symphonya.unimib.it), (3), 1-10.

http://dx.doi.org/10.4468/2017.3.01ouverture 
Brondoni, S. M. (2016). Global Tourism Management. Mass, Experience and Sensations Tourism. Symphonya. Emerging Issues in Management (symphonya.unimib.it), (1), 7-24.

http://dx.doi.org/10.4468/2016.1.02brondoni

Dinda, S. (2004). Environmental Kuznets Curve Hypothesis: A Survey. Ecological Economics, 49(4), 431-455.

http://dx.doi.org/10.1016/J.ECOLECON.2004.02.011

Dumitrescu, E.-I., \& Hurlin, C. (2012). Testing for Granger Non-Causality in Heterogeneous Panels. Economic Modelling, 29(4), 1450-1460.

http://dx.doi.org/10.1016/J.ECONMOD.2012.02.014

Engle, R. F., \& Granger, C. W. J. (1987). Co-Integration and Error Correction: Representation, Estimation, and Testing. Econometrica, 55(2), 251.

http://dx.doi.org/10.2307/1913236

Farrell, B. H., \& Twining-Ward, L. (2004). Reconceptualizing Tourism. Annals of Tourism Research, 31(2), 274-295.

http://dx.doi.org/10.1016/J.ANNALS.2003.12.002

Fayissa, B., Nsiah, C., \& Tadesse, B. (2011). Tourism and Economic Growth in Latin American Countries - Further Empirical Evidence. Tourism Economics, 17(6), 1365-1373.

http://dx.doi.org/10.5367/te.2011.0095

Garau Taberner, J. M. (2010). Tourist Satisfaction, Dissatisfaction and Place Attachment at Sun and Sand Mass Tourism Destinations. Universitat de les Illes Balears.

Georgescu-Roegen, N., Naredo, J., \& Grinevald, J. (1996). La Ley de la Entropía y el Proceso Económico. Fundación Argentaria.

Gössling, S. (2017). Tourism, Information Technologies and Sustainability: An Exploratory Review. Journal of Sustainable Tourism, 25(7), 1024-1041.

http://dx.doi.org/10.1080/09669582.2015.1122017

Gössling, S., Hansson, C. B., Hörstmeier, O., \& Saggel, S. (2002). Ecological Footprint Analysis as a Tool to Assess Tourism Sustainability. Ecological Economics, 43(2-3), 199-211.

http://dx.doi.org/10.1016/S0921-8009(02)00211-2

Gössling, S., \& Peeters, P. (2015). Assessing Tourism's Global Environmental Impact 1900-2050. Journal of Sustainable Tourism, 23(5), 639-659.

http://dx.doi.org/10.1080/09669582.2015.1008500

Gössling, S., Peeters, P., Ceron, J.-P., Dubois, G., Patterson, T., \& Richardson, R. B. (2005). The EcoEfficiency of Tourism. Ecological Economics, 54(4), 417-434.

http://dx.doi.org/10.1016/J.ECOLECON.2004.10.006

Kallis, G., Kerschner, C., \& Martinez-Alier, J. (2012). The Economics of Degrowth. Ecological Economics, 84, 172-180.

http://dx.doi.org/10.1016/J.ECOLECON.2012.08.017

Kumar, R. R., \& Kumar, R. (2012). Exploring the Nexus Between Information and Communications Technology, Tourism and Growth in Fiji. Tourism Economics, 18(2), 359-371.

http://dx.doi.org/10.5367/te.2012.0117

Kuznets, S. (1955). Economic Growth and Income Inequality. The Economic Journal, 45(1), 1-28.

http://dx.doi.org/10.2307/2223489

Li, K. X., Jin, M., \& Shi, W. (2018). Tourism as an Important Impetus to Promoting Economic Growth: A Critical Review. Tourism Management Perspectives, 26, 135-142.

http://dx.doi.org/10.1016/J.TMP.2017.10.002

Louis, T., \& John, A. (1991). La Horda Dorada. El turismo Internacional y la Periferia del Placer. Editorial Endymion, Madrid.

Luo, X., \& Bao, J. (2019). Exploring the Impacts of Tourism on the Livelihoods of Local Poor: The Role of Local Government and Major Investors. Journal of Sustainable Tourism, 27(3), 344-359. http://dx.doi.org/10.1080/09669582.2019.1578362 
Manera, C., \& Navines, F. (2018). La Industria Invisible. Palma: Lleonard Muntaner.

Manera Erbina, C. P. (2014). La Internacionalización de las Cadenas Hoteleras Españolas. El caso de Baleares 1980-2012. Revista de La Historia de La Economía y de La Empresa, (8), 185-213.

Maroto-Sánchez, A., \& Cuadrado-Roura, J. R. (2009). Is Growth of Services an Obstacle to Productivity Growth? A Comparative Analysis. Structural Change and Economic Dynamics, 20(4), 254-265.

http://dx.doi.org/10.1016/J.STRUECO.2009.09.002

Morley, C. L. (1992). A Microeconomic Theory of International Tourism Demand. Annals of Tourism Research, 19(2), 250-267.

http://dx.doi.org/10.1016/0160-7383(92)90080-9

Mullins, P. (1991). Tourism Urbanization. International Journal of Urban and Regional Research, 15(3), 326-342.

http://dx.doi.org/10.1111/j.1468-2427.1991.tb00642.x

Murray, I. (2002). La Petjada Ecològica de les Illes Balears. Estudis d'historia Econòmica, (19), 103-150.

Murray, I. (2013). Algunes Notes Sobre el Turisme y la Forma en Què les Ciències Socials l'han Abordat Críticament. Geo-Crítica, 13(1016).

O’Reilly, A. M. (1986). Tourism Carrying Capacity: Concept and Issues. Tourism Management, 7(4), 254-258.

http://dx.doi.org/10.1016/0261-5177(86)90035-X

Papatheodorou, A., \& Song, H. (2005). International Tourism Forecasts: Time-Series Analysis of World and Regional Data. Tourism Economics, 11(1), 11-23.

http://dx.doi.org/10.5367/0000000053297167

Paramati, S. R., Alam, M. S., \& Chen, C.-F. (2017). The Effects of Tourism on Economic Growth and CO 2 Emissions: A Comparison between Developed and Developing Economies. Journal of Travel Research, 56(6), 712-724.

http://dx.doi.org/10.1177/0047287516667848

Pearce, D. G. (1989). International and Domestic Tourism: Interfaces and Issues. GeoJournal, 19(3), 257-262.

http://dx.doi.org/10.1007/BF00454569

Pearce, D. G. (1998). Tourism Development in Paris: Public Intervention. Annals of Tourism Research, 25(2), 457-476.

http://dx.doi.org/10.1016/S0160-7383(97)00096-0

Pedroni, P. (1999). Critical Values for Cointegration Tests in Heterogeneous Panels with Multiple Regressors. Oxford Bulletin of Economics and Statistics, 61(s1), 653-670.

http://dx.doi.org/10.1111/1468-0084.0610s1653

Pedroni, P. (2004). Panel Cointegration: Asymptotic and Finite Sample Properties of Pooled Time Series Tests with an Application to the PPP Hypothesis. Econometric Theory, 20(03), 597-625. http://dx.doi.org/10.1017/S0266466604203073

Pesaran, M. H. (2007). A Simple Panel Unit Root Test in the Presence of Cross-Section Dependence. Journal of Applied Econometrics, 22(2), 265-312.

http://dx.doi.org/10.1002/jae.951

Pesaran, M. H., Ullah, A., \& Yamagata, T. (2008). A Bias-Adjusted LM Test of Error Cross-Section Independence. The Econometrics Journal, 11(1), 105-127.

http://dx.doi.org/10.1111/j.1368-423X.2007.00227.x

Pesaran, M., \& Yamagata, T. (2008). Testing Slope Homogeneity in Large Panels. Journal of Econometrics, 142(1), 50-93.

http://dx.doi.org/10.1016/J.JECONOM.2007.05.010

Podhorodecka, K. (2018). Tourism Economies and Islands' Resilience to the Global Financial Crisis. Island Studies Journal, 13(2).

Poon, A. (1993). Tourism, Technology and Competitive Strategies. New York: CAB International. 
Pueyo, S. (2014). Ecological Econophysics for Degrowth. Sustainability, 6(6), 3431-3483.

http://dx.doi.org/10.3390/su6063431

Rizzi, P., \& Graziano, P. (2017). Regional Perspective on Global Trends in Tourism. Symphonya. Emerging Issues in Management (symphonya.unimib.it), (3), 11-26.

http://dx.doi.org/10.4468/2017.3.02rizzi.graziano

Rodrik, D. (2016). Premature Deindustrialization. Journal of Economic Growth, 21(1), 1-33.

http://dx.doi.org/10.1007/s10887-015-9122-3

Salvioni, D. M. (2016). Hotel Chains and the Sharing Economy in Global Tourism. Symphonya. Emerging Issues in Management (symphonya.unimib.it), (1), 31-44.

http://dx.doi.org/10.4468/2016.1.04salvioni

Schlupmann, K., \& Martinez-Alier, J. (1987). Ecological Economics: Energy, Environment and Society. Oxford: Blackwell Publishers Ltd.

Scott, D. (2011). Why Sustainable Tourism Must Address Climate Change. Journal of Sustainable Tourism, 19(1), 17-34.

http://dx.doi.org/10.1080/09669582.2010.539694

Scott, D., Peeters, P., \& Gössling, S. (2010). Can Tourism Deliver Its “Aspirational” Greenhouse Gas Emission Reduction Targets? Journal of Sustainable Tourism, 18(3), 393-408.

http://dx.doi.org/10.1080/09669581003653542

Segreto, L., Manera, C., \& Pohl, M. (2009). Europe at the Seaside: The Economic History of Mass Tourism in the Mediterranean. Berghahn Books.

Sindinga, I. (1999). Alternative Tourism and Sustainable Development in Kenya. Journal of Sustainable Tourism, 7(2).

Sun, Y.-Y., Lenzen, M., \& Liu, B.-J. (2019). The National Tourism Carbon Emission Inventory: Its Importance, Applications and Allocation Frameworks. Journal of Sustainable Tourism, 27(3), 360379.

http://dx.doi.org/10.1080/09669582.2019.1578364

Tang, Z., Shang, J., Shi, C., Liu, Z., \& Bi, K. (2014). Decoupling Indicators of CO2 Emissions from the Tourism Industry in China: 1990-2012. Ecological Indicators, 46, 390-397.

http://dx.doi.org/10.1016/J.ECOLIND.2014.06.041

Turner, G. M. (2012). On the Cusp of Global Collapse? Updated Comparison of The Limits to Growth with Historical Data. GAIA - Ecological Perspectives for Science and Society, 21(2), 116-124.

http://dx.doi.org/10.14512/gaia.21.2.10

Weaver, D. (2011). Can Sustainable Tourism Survive Climate Change? Journal of Sustainable Tourism, 19(1), 5-15.

http://dx.doi.org/10.1080/09669582.2010.536242

Williams, A., \& Shaw, G. (1998). Tourism and the Environment: Sustainability and Economic Restructuring, in Hall, M. \& Lew, A. A. (eds.), Sustainable Tourism. A Geographical Perspective (pp. 49-59). Addison Wesley Longman Ltd. 